\title{
ANTICANCER ACTIVITY OF GARCINIA MORELLA CHLOROFORM FRACTION AND ITS ACTIVE COMPOUND GARCINOL ON NEUROBLASTOMA
}

\author{
BHASWATI CHOUDHURY ${ }^{1 *}$, RAGHURAM KANDIMALLA ${ }^{1}$, RUPJYOTI BHARALI' ${ }^{2}$, JIBON KOTOKY ${ }^{1}$ \\ ${ }^{1}$ Drug Discovery Laboratory, Life sciences division, Institute of Advanced studies in Science and technology, Drug Discovery Lab., Paschim \\ Boragaon, Guwahati, Assam, India. ${ }^{2}$ Department of Biotechnology, Gauhati University, Guwahati, Assam, India. \\ Email: bhaswatichoudhury@ymail.com \\ Received: 03 July 2017, Revised and Accepted: 25 August 2017
}

ABSTRACT

Objective: The aim of the present study is to evaluate the anticancer activity of $G$. morella fruit chloroform fraction and its isolated bioactive molecule garcinol on neuroblastoma cell line (SH-SY5Y).

Method: Methanol extraction was performed for the G. morella fruits through cold maceration and further fractionated with chloroform. The presence of Garcinol was confirmed by measuring the melting point. Further, the bioactive chloroform fraction and pure Garcinol was tested for anticancer activity against SH-SY5Y cells through MTT assay.

Result: The present study reveals the anticancer ability of bioactive chloroform fraction of $G$. morella fruit and its active molecule garcinol.

Conclusion: G. morella fruit and its bioactive compound Garcinol have significant activity against neuroblastoma. This study opens an avenue to further elucidate the mechanism of action and development of alternative treatment of this dreaded disease.

Keywords: Garcinia morella, Neuroblastoma, Garcinol, Anticancer activity.

(C) 2017 The Authors. Published by Innovare Academic Sciences Pvt Ltd. This is an open access article under the CC BY license (http://creativecommons. org/licenses/by/4. 0/) DOI: http://dx.doi.org/10.22159/ajpcr.2017.v10i12.21066

\section{INTRODUCTION}

Plants are integral part of the medicinal system from ancient time. Many local and tribal groups all over the world still depend completely on natural remedies based mainly on plants. According to an official report by the World Health Organization approximately $80 \%$ of the world populations still rely on phytotherapy [1]. However, owing to the lack of scientific validation and proper documentation of the processing of such plants for medicinal purposes, they are yet to attain their status. Hence, researchers from all over the world are now interested in plant-based drug discovery research. $25 \%$ of the small drug molecule approved in 2014 are natural product based. The biological properties of plants can be attributed to their chemical constituents. Privileged chemical structures from nature are chosen as backbone for many new chemical entities developed for targeting various diseases [2].

Plants of the genus Garcinia are reported to possess antibacterial [3,4], antifungal [5], antioxidant [6], anti-inflammatory [7], and anticancer $[8,9]$ activity. Many important chemical constituents are reported to be isolated from plants of these genus such as garcinol, isogarcinol, alpha mangosteen, beta mangosteen, gambogenic acid [10-12]. Garcinia morella is a lesser explored plant of this genus and mainly found in northeastern region of India, Southern region of India, China, and Sri Lanka. It is commonly called as Kuji Thekera in Assam. The fruit of this plant is used in traditional medicine system for treatment of inflammatory disorders, bowel syndromes, wound healing, and tumors.

Neuroblastoma is childhood tumor associated with the sympathetic nervous system. It is aggressive tumor with severe clinical complexities often leading to high rate of mortality. Neuroblastoma is characterized to have cellular heterogeneity and human neuroblastoma derived cell lines retain the heterogeneous character [13]. Even with the recent advancements of medical field, still, neuroblastoma accounts for approximately $15 \%$ of cancer deaths in younger children [14]. Hence, novel chemotherapeutic agents from natural sources are much sought for treatment of such form of deadly cancer.

In our previous report, we demonstrated the anticancer activity of $G$. morella fruit on T-cell murine lymphoma in in vitro and in vivo condition [9]. Since there are no earlier reports of anticancer activity of $G$. morella fruit on neuroblastoma, we have taken up this study to support our claim of $G$. morella fruit to a be a rich source of anticancer compounds. Moreover, Garcinol isolated from plants of Garcinia family are reported to have remarkable anticancer efficacy, but there are no reports highlighting its effect on neuroblastoma. Thereby, we embarked on this preliminary study to establish the anticancer potential of Garcinol on neuroblastoma cell line SH-SY5Y.

\section{METHODS}

Collection and identification of plant samples

G. morella fruits were collected from Sorbhog, Patchala district, Assam, India (N26.33'37E091.00'99) during the month of February, 2012. The plant sample was identified and authenticated by taxonomist at Northeast Indian Ayurvedic Research Institute (Government of India) Guwahati, Assam, India. The fruit sample was preserved and herbarium was prepared and deposited in drug Discovery Laboratory, Institute of Advanced study in Science and Technology, Guwahati with voucher no IASST/BCCS/HNO112/2012.

\section{Preparation of extract}

The fruit samples were finely cut into small pieces and air dried. The dried pericarps were grounded to coarse powder and extracted at room temperature by continuous stirring in methanol for 3 consecutive days. The extract was filtered and the solvent was evaporated by rotar evaporator at $45^{\circ} \mathrm{C}$. The dried extract obtained was further aseptically air dried and stored in closed container at $4^{\circ} \mathrm{C}$ 
Phytochemical analysis

Methanol extract of $G$. morella was phytochemically investigated by standard protocols [15].

\section{Fractionation of $G$. morella crude extract}

$1 \mathrm{~kg}$ of $G$. morella crude methanol extract was loaded to a silica gel column and eluted with solvents in increasing polarity such as hexane: Ethyl acetate, ethyl acetate, chloroform, and methanol: Chloroform. The fractions were collected separately and rotor evaporated. The dried samples were stored in tight containers at $4^{\circ} \mathrm{C}$ for biological assays.

\section{Identification of garcinol in chloroform fraction}

The chloroform fraction was further fractionated in flash chromatography. $1.2 \mathrm{~g}$ chloroform fraction was loaded in $12 \mathrm{~g}$ silica gel column and eluted with hexane: Ethyl acetate gradient. The eluent of each peak was separately collected with regular monitoring by thinlayer chromatography. A yellow powder obtained in subfraction 23 was identified by determination of melting point of the compound.

\section{Anticancer activity}

Chemicals

Dulbecco's modified eagle's medium (DMEM), fetal bovine serum (FBS), trypsin ethylenediaminetetraacetic acid (EDTA), phosphate buffered saline, pentsrep, dimethyl sulfoxide (DMSO), and 3-(4,5dimethyl thiazol-2-yl)-2,5-diphenyl tetrazolium bromide (MTT) were procured from Sigma Aldrich Co., St. Louis USA. Solvents Methanol, Chloroform, Hexane, and Ethylacetate were purchased from Merck Ltd., Mumbai, India. Garcinol was procured from Santa Cruz Biotechnology Inc.

\section{Cell culture}

Neuroblastoma cell line (SH-SY5Y) was obtained from National centre for cell science, Pune. SH-SY5Y cells were maintained in DMEM with $10 \%$ FBS and $1 \%$ Pen strep in humidified atmosphere of $5 \% \mathrm{CO}_{2}$ incubator at $37^{\circ} \mathrm{C}$. The cells were grown in T-25 flask till confluent then they were dissociated from the flask by trypsin EDTA. The dissociated cells were counted using cell counter. All the cytotoxic assays were carried out using 96 well culture plates (Tarsons, India Pvt. Ltd., Kolkata, India).

\section{Drug preparation}

Stock solution of Garcinia morella fruit chloroform fraction (GFCH) $(100 \mathrm{mg} / \mathrm{ml})$ was prepared in 100\% DMSO. Different dilutions of GFCH were made in incomplete sterile DMEM. Garcinol was dissolved in $100 \%$ DMSO at a concentration of $10 \mathrm{~mm}$. The stock solution was further diluted in incomplete DMEM for experiments.

\section{Evaluation of cytoxicity of the test samples by MTT assay}

Anticancer activity of chloroform fraction GFCH and garcinol on neuroblastoma cell line SHSY5Y was determined by MTT assay [16-18]. Briefly, SHSY5Y cells were seeded in 96 well plates at a density of 5000 cells per well in DMEM media and 10\% FBS and 1\% Pen strep and plates were incubated overnight in a $5 \% \mathrm{CO}_{2}$ incubator. After $24 \mathrm{hrs}, \mathrm{GFCH}$ at doses of $1.56,3.12,6.25,12.5$, and $25 \mu \mathrm{g} / \mathrm{ml}$ and garcinol at concentrations of $2.5,5,10$, and $20 \mu \mathrm{m}$ were added to the respective wells. The plates were incubated for 24,48 , and $72 \mathrm{hrs}$. At the commencement of drug treatment period of each plate, they were removed from the incubator, and the media containing drug was disposed. Fresh media was filled in each well preceded by addition of $4 \mathrm{mg} / \mathrm{ml}$ of MTT solution. The plates were then kept at $37^{\circ} \mathrm{C}$ incubator in dark for $4 \mathrm{hrs}$. After the reaction period, the media containing MTT was disposed from the wells and the Formazan formed at the bottom of the well was suspended in DMSO. The plates were then read at $570 \mathrm{~nm}$ in a multimode reader. The optical density of each well was recorded and the percentage inhibition of proliferation of the neuroblastoma cells by treatment with different doses of the drugs were calculated by the formula:

\author{
Percentage of live cells $(\%)=$ \\ Mean OD of test sample - Mean OD of blank \\ Mean OD of control - Mean OD of blank $\times 100$
}

Percentage inhibition of the drug $=100$-percentage of live cells $(\%)$.

\section{RESULTS}

\section{Phytochemical analysis}

From Table 1, G. morella fruit was found to be composed of phytochemicals such as flavonoid, phenol, saponin, tannin, steroid, and terpenoid.

Compound 23 was found to have a melting point $132^{\circ} \mathrm{C}$. With literature survey of other plants of Garcinia family, compound 23 was hinted to be garcinol.

\section{Anticancer assays}

The results of the MTT assay clearly show the dose and time-dependent activity of GFCH against neuroblastoma cell line SHSY5Y. IC ${ }_{50}$ of GFCH on SH-SY5Y cells after an exposure time of $24 \mathrm{~h}, 48 \mathrm{~h}$ and $72 \mathrm{~h}$ was found to be $5.3,4.32$, and $3.96 \mu \mathrm{g} / \mathrm{ml}$, respectively. At all durations of exposure to GFCH, the activity of GFCH on SHSY5Y was found to be dose dependent, i.e., the percentage inhibition of proliferation of SHSY5Y was increasing with increasing concentrations of GFCH (Fig. 1) Lower value of $\mathrm{IC}_{50}$ at longer duration of treatment period indicated that GFCH-induced highest activity at $72 \mathrm{hrs}$ (Table 2). In a similar study through MTT assay, IC $_{50}$ of Datura metel leaf and stem extract was evaluated against Vero and MCF7 cell line [19]. In another study, $\mathrm{IC}_{50}$ of Stephania elegans on MCF7 was reported to be $158.7 \pm$ $0.13 \mu \mathrm{g} / \mathrm{ml}[20]$.

Similarly, anticancer activity of different concentrations of garcinol on neuroblastoma cell line SHSY5Y for different doses and period revealed that garcinol-induced significant dose and time activity against SHSY5Y cells (Fig. 2). IC $_{50}$ of garcinol on SHSY5Y at 24, 48, and $72 \mathrm{hrs}$ was found to be $7.78,6.80$, and $6.30 \mu \mathrm{m}$, respectively (Table 2). Interestingly, IC50 doses of both GFCH and Garcinol were found to decrease upon increasing the exposure time. Thus, at the longest duration of the treatment period ( $72 \mathrm{~h}), \mathrm{GFCH}$ and garcinol induced the highest activity.

\section{DISCUSSION}

According to American cancer society 2009-2013, Neuroblastoma is the third most popular type of cancer detected in children and adolescents. Neuroblastoma is reported to be resistant to chemotherapeutic drugs and display traits of recurrence [21]. Thus, research towards the identification of novel anti-neuroblastoma agents and their subsequent development into drugs is still recommended to improve the patient condition.

Recent studies have revealed the capability of various plant based products in inhibiting the proliferation of several cancer cell lines including neuroblastoma [22-24]. Plants of Garcinia family are cited to have anticancer activity against different types of cancer cell lines. But to our knowledge, the activity of G. morella has never been investigated against neuroblastoma. Thereby, in the present study, for the first time, we reported the remarkable efficacy of $G$. morella fruit against neuroblastoma. In similar studies, the n-Hexane fraction of Nardostachys jatamansi was reported to have exhibited $54 \%$ and $91 \%$ inhibition against neuroblastoma cell line at 30 and $100 \mu \mathrm{g} / \mathrm{ml}$ respectively[24]. Similarly, Saussurea lappa Clarke root extract was found to induce dose dependent activity against neuroblastoma cell line via apoptotic pathway [25]. From our results, we can interpret that GFCH has a higher cytotoxic potential (IC50 $5.3 \mu \mathrm{g}$ / $\mathrm{ml}$ at $24 \mathrm{~h}$ ) on neuroblastoma than the other previously reported plant crude extracts. In our previous study, we have demonstrated the apoptosis inducing the effect of G. morella fruit extract on Dalton's ascites lymphoma cells by activation of caspases [9]. In the present study, we can hypothesise the involvement of apoptotic markers in bestowing cytotoxic potential to G. morella fruit against neuroblastoma. 

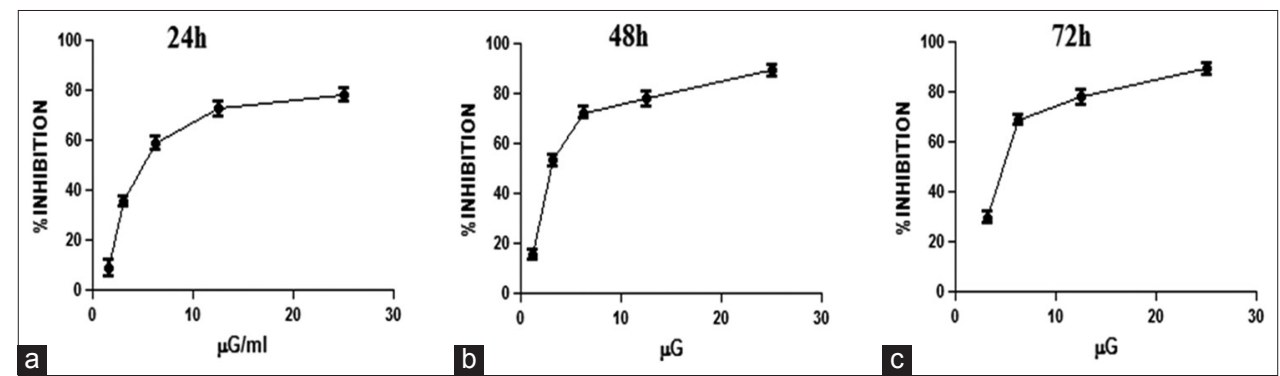

Fig. 1: Effect of GFCH $(\mu \mathrm{g} / \mathrm{ml})$ on the proliferation of SH-SY5Y cells after treatment for (A) $24 \mathrm{~h},(\mathrm{~B}) \mathbf{4 8 h}$ and (C) $72 \mathrm{~h}$. Results are expressed as mean \pm S.D. (standard deviations), ( $\mathrm{N}=6$ ). GFCH: chloroform fraction of Garcinia morella.

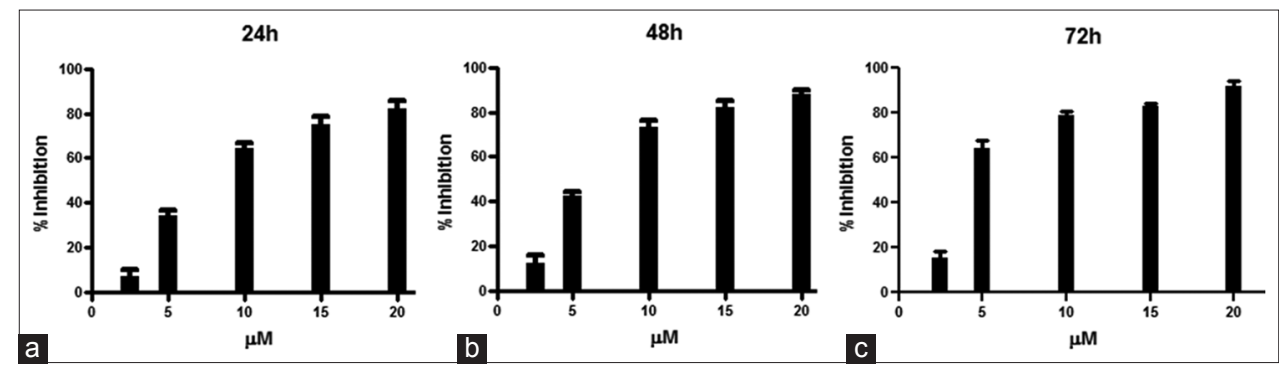

Fig 2: Effect of Garcinol ( $\mu \mathrm{M})$ on the proliferation of SH-SY5Y after treatment for (A) $24 \mathrm{~h}$, (B) $48 \mathrm{~h}$ and (C) $72 \mathrm{~h}$. All the results are expressed as mean \pm S.D. (standard deviations), $(n=6)$.

Table 1: Phytochemical analysis of G. morella fruit chloroform fraction

\begin{tabular}{lllllll}
\hline Extracts & Flavonoid & Tannin & Saponin & Phenol & Steroid & Terpenoid \\
\hline GFM & +++ & +++ & +++ & +++ & ++ & \\
\hline
\end{tabular}

GFM: Garcinia morella fruit methanol extract. G. Morella: Garcinia morella

Polyisoprenylated benzophenone, Garcinol is isolated from different species of Garcinia family especially from G. indica and G. mangostana. Many studies have reported the significant anticancer activity of Garcinol on a diverse range of cancer cell lines. Garcinol is reported to have dose dependent activity against prostate cancer cell lines PC-3, LNCaP and DU-145 [26]. The types of cancer on which cytotoxic effect of garcinol is tested are breast cancer [27], Burkitt lymphoma [28], Colon cancer [29], esophageal cancer [27], hepatocellular carcinoma [30]. We assume that garcinol exhibits anticancer activity against neuroblastoma through triggering the apoptotic cascade.

\section{CONCLUSION}

The results of this study indicate that $G$. morella fruit can be a potential anticancer source against neuroblastoma. More importantly, garcinol the main bioactive molecule of $G$. morella chloroform fraction was found to be highly effective against this cancer. Thereby, our study instigates new research in this direction which may lead to the development of a novel drug for treatment of neuroblastoma.

\section{ACKNOWLEDGMENT}

Authors are very much thankful to Department of Science and Technology, the Government of India, New Delhi for providing the financial support to conduct this study and the host institute, Institute of Advanced study in science and technology in providing necessary facilities.

\section{AUTHOR CONTRIBUTION}

Ms. Choudhury is the main author of this research work including study design, experimental setup and writing of the manuscript. She performed all the experiments. Mr. Kandimalla contributed towards study design and compilation of data. Dr. Kotoky and Dr. Bharali supervised the design of experiments and assessment of results.
Table 2: $\mathrm{IC}_{50}$ of GFCH and garcinol on SH-SY5Y

\begin{tabular}{llll}
\hline Drugs & $\mathbf{2 4} \mathbf{~ h r s}$ & $\mathbf{4 8} \mathbf{~ h r s}$ & $\mathbf{7 2} \mathbf{~ h r s}$ \\
\hline GFCH $(\mu \mathrm{g} / \mathrm{ml})$ & 5.3 & 4.32 & 3.96 \\
Garcinol $(\mu \mathrm{m})$ & 7.78 & 6.80 & 6.30 \\
\hline
\end{tabular}

GFCH: Garcinia morella fruit chloroform fraction, $\mathrm{IC}_{50}$ : Inhibitory concentration

\section{REFERENCES}

1. Pathare YS, Wagh VD. Herbal medicines and nutritional supplements used in the treatment of Glaucoma: A review. Res J Pharm Biol Chem Sci 2012;3(1):331-9.

2. Newman DJ, Cragg GM. Natural Products as Sources of New Drugs from 1981 to 2014. J Nat Prod 2016;79(3):629-61.

3. Rao KV, Rao PL. Antibiotic principles of Garcinia morella: IX. Antimicrobial activity of alpha \& beta-guttiferins \& their derivatives. Indian J Exp Biol 1967;5(2):101-5.

4. Santhanam K, Narasimha Rao PL. Antibiotic principles of Garcinia morella: 13 Antimicrobial activity and toxicity of alpha 1 and $\mathrm{Y}$ guttiferins and their derivatives. Indian J Exp Biol 1969;7(1):34-6.

5. Abah AA, Agbelusi GA, Odukoya OA, Ayanbadejo PO, AdefuleOsitelu AO, Adebiyi KE. Garcinia Kola extracts as antifungal therapy for oral Candida infections a comparative study. J Dent Med Sci 2014;13(11):20-4.

6. Tan WN, Khairuddean M, Wong KC, Tong WY, Ibrahim D. Antioxidant compounds from the stem bark of Garcinia atroviridis. J Asian Nat Prod Res 2016;18(8):804-11.

7. Chen LG, Yang LL, Wang CC. Anti-inflammatory activity of mangostins from Garcinia mangostana. Food Chem Toxicol 2008;46(2):688-93.

8. Mohamed GA, Al-Abd AM, El-Halawany AM, Abdallah HM, Ibrahim SR. New xanthones and cytotoxic constituents from Garcinia mangostana fruit hulls against human hepatocellular, breast, and colorectal cancer cell lines. J Ethnopharmacol 2017;198:302-12.

9. Choudhury B, Kandimalla R, Bharali R, Monisha J, Kunnumakara AB, Kalita K, et al. Anticancer Activity of Garcinia morella on T-cell murine lymphoma via apoptotic induction. Front Pharmacol 2016;7:3. 
10. Shibata MA, Iinuma M, Morimoto J, Kurose H, Akamatsu K, Okuno Y, et al. A mangos tin extracted from the pericarp of the Mangosteen (Garcinia mangostana Linn) reduces Tumor growth and lymph node metastasis in an immunocompetent xenograft model of metastatic mammary cancer carrying a p53 mutation. BMC Med 2011;9:69.

11. Ahmad A, Sarkar SH, Aboukameel A, Ali S, Biersack B, Seibt $\mathrm{S}$, et al. Anticancer action of garcinol in vitro and in vivo is in part mediated through inhibition of STAT-3 signaling. Carcinogenesis 2012;33(3):2450-6.

12. Zhou J, Luo YH, Wang JR, Lu BB, Wang KM, Tian Y. Gambogenic acid induction of apoptosis in a breast cancer cell line. Asian Pac J Cancer Prev 2013;14(12):7601-5.

13. Hallett A, Traunecker H. A review and update on Neuroblastoma. J Paediatr Child Health 2012;22(3):103-7.

14. Maris JM, Hogarty MD, Bagatell R, Cohn SL. Neuroblastoma. Lancet 2007;369(9579):2106-20.

15. Kandimalla R, Dash S, Kalita S, Choudhury B, Malampati S, Kalita K, et al. Protective effect of bioactivity guided fractions of Ziziphus jujuba Mill. Root bark against hepatic injury and chronic inflammation via inhibiting inflammatory markers and oxidative stress. Front Pharmacol 2016;7:298

16. Sridevi M, John B, Yamini K. Anti-cancer effect of Ocium sanctum ethanolic extract on non-small cell lung carcinoma cell. Int J Pharm Pharm Sci 2016;8(4):242-6.

17. Kandimalla R, Dash S, Kalita S, Choudhury B, Malampati S, Kalita K, et al. Bioactive guided fractions of Annona reticulata L. bark: Protection against liver toxicity and inflammation through inhibiting oxidative stress and proinflammatory cytokines. Front Pharmacol 2016;7:168.

18. Gajjar DG, Patel RM, Patel VA, Patel PK. Novel hydroxyl terminated dendrimers as potential drug carriers: Sustained release, hemolysis and cytotoxicity study. Int J App Pharm 2015;7:5-9.

19. Nazeema BB, Julie J, Abirami J, Kumareasan R, Muthukumaran T, Rajasree S, et al. Anti-cancer activity of Datura metel on mcf-7 cell line. Asian J Pharm Clin Res 2014;7(1):181-3.

20. Sharma R, Chandan G, Chahal A, Saini RV. Antioxidant and anticancer activity of methanolic extract from Stephania elegans. Int J Pharm
Pharm Sci 2017:9(2):245-9.

21. Maris JM, Hogarty MD, Bagatell R, Cohn SL. Neuroblastoma. Lancet 2007;369:2106-20

22. Al-Oqail MM, Al-Sheddi ES, Siddiqui MA, Musarrat J, AlKhedhairy AA, Farshori NN. Anticancer activity of chloroform extract and sub-fractions of Nepeta deflersiana on human breast and lung cancer cells: An in vitro cytotoxicity assessment. Pharmacogn Mag 2015;11:598-605.

23. Artun FT, Karagoz A, Ozcan G, Melikoglu G, Anil S, Kultur S, et al. In vitro anticancer and cytotoxic activities of some plant extracts on HeLa and Vero cell lines. J BUON 2016;21:720-5.

24. Panditaa RM, Bhagat M, Saxena AK. Evaluation of in vitro cytotoxicity of Nardostachys jatamansi roots extracts and fractions against neuroblastoma human cancer cell lines. J Pharm Res 2012;5:2720-22.

25. Rahman MA, Bishayee K, Huh SO. Angelica polymorpha maxim induces apoptosis of human SH-SY5Y neuroblastoma cells by regulating an intrinsic caspase pathway. Mol Cells 2016;39:119-28.

26. Wang Y, Tsai ML, Chiou LY, Ho CT, Pan MH. Antitumor activity of garcinol in human prostate cancer cells and xenograft mice. J Agric Food Chem 2015;63:9047-52.

27. Prasad S, Ravindran J, Sung B, Pandey MK, Aggarwal BB. Garcinol potentiates TRAIL-induced apoptosis through modulation of death receptors and antiapoptotic proteins. Mol Cancer Ther 2010; 9:856-68

28. Ito C, Itoigawa M, Miyamoto $\mathrm{Y}$, Onada S, Rao KS, Mukainaka T, et al. Polyprenylated benzophenones from Garcinia assigu and their potential cancer chemopreventive activities. J Nat Prod 2003;66:206-9.

29. Hong J, Kwon SJ, Sang S, Ju J, Zhou JN, Ho CT, et al. Effects of garcinol and its derivatives on intestinal cell growth: Inhibitory effects and autoxidation-dependent growth-stimulatory effects. Free Radical Biol Med 2007;42:1211-21.

30. Ohnishi H, Asamoto M, Tujimura K, Hokaiwado N, Takahashi S, Ogawa $\mathrm{K}$, et al. Inhibition of cell proliferation by nobiletin, a dietary phytochemical, associated with apoptosis and characteristic gene expression, but lack of effect on early rat hepatocarcinogenesis in vivo. Cancer Sci 2004;95:936-42. 